\title{
Menghindari Corona
}

\section{Bagian 4 Ujian On Line}

Muhammad Rais Rahmat Razak

mraisrahmat@umrappang.ac.id

mraisrahmat@gmail.com

\section{Ujian On line} dengan SOCRATIVE

(www, Socrative.com)

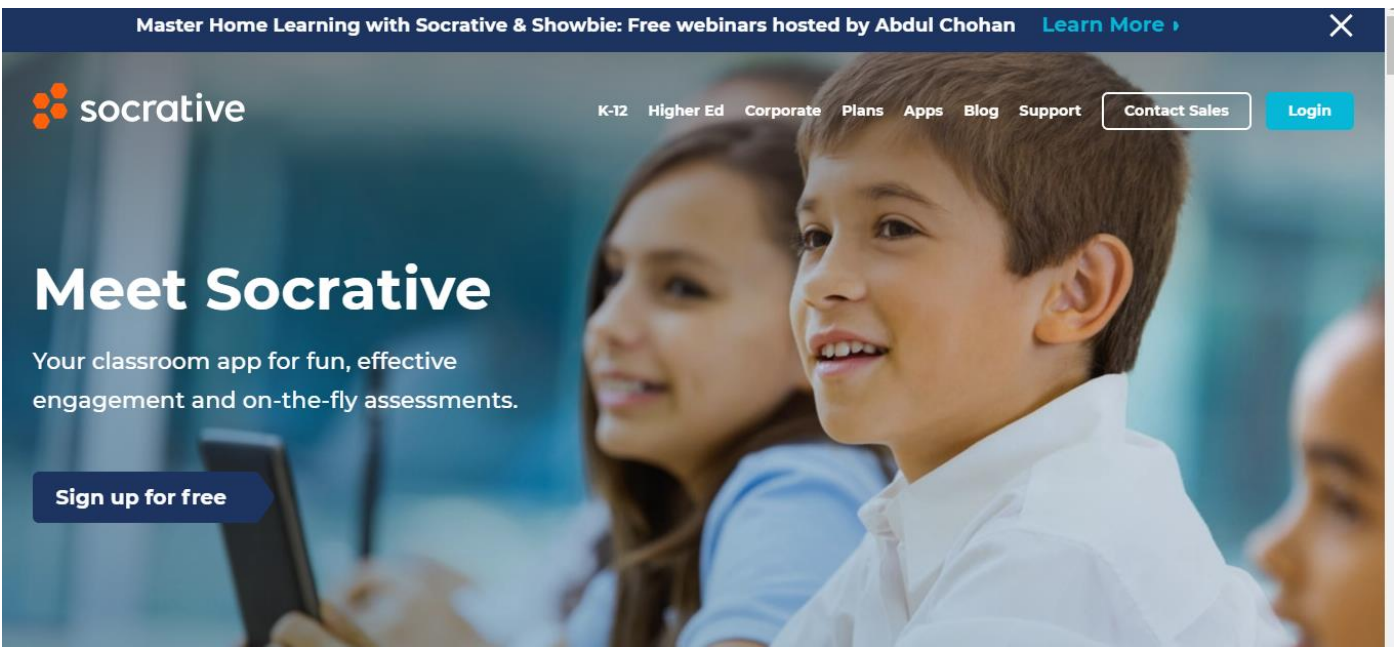

Dosen MK. : Teknologi Sistem Informasi

Universitas Muhammadiyah Sidenreng Rappang 


\section{Abstrak}

Covig-19 memposisikan diri sebagai wabah dunia, karena penyebarannya cepat dan menimbulkan korban ribuan meninggal. Virus yang menurut media awalnya ditemukan berasal dari Wuhan China, kemudian menyebar cepat dan sekarang beberapa negara maju sudah menerapkan kebijakan LOCKDOWN seperti Italia, Spanyol, Amerika, Chine, dll. Covig-19 membawa perubahan cepat kepada prilaku manusia, pemerintah Indonesia menganjurkan social distancing daripada lock down, namun keyataannya beberapa daerah seperti Tegal menerapkan lockdown kemudian diralat menjadi lockdown wilayah. Dalam dunia pendidikan, kebijakan social distance kemudian diterapkan disekolah dan perguruan tinggi untuk mengganti proses belajar dari sebelumnya tatap muka menjadi daring. Hal ini menciptakan masalah baru, bagaimana dengan pelaksanaan ujiannya. Tulisan ini bertujuan untuk mencari metode dan aplikasi kemudian membuat pedomannya . Dengan penggunaan aplikasi socrative yang tersedia di internet dapat membantu mahasiswa dan dosen dalam melaksanakan ujian. Hasil penelusuran dan diskusi dengan mahasiswa dan dibuat dalam bentuk pedoman, maka dapat disimpulkan bahwa, aplikasi socrative dapat digunakan sebagai salah satu metode pelaksanaan ujian yang murah dan mudah dijalankan.

Keyword : covig-19; socrative; pelaksanaan ujian; social distance 


\section{SOCRATIVE untuk DOSEN (Ujian on Line)}




\section{Panduan Membuat Soal}

1.1. Buka link atau cari di gogle atau mesin pencari lainnya dengan socrative, muncul www.socrative.com.

2. Klik, www.socrative.com maka muncul tampilan seperti dibawah ini,

3. Klik, Login

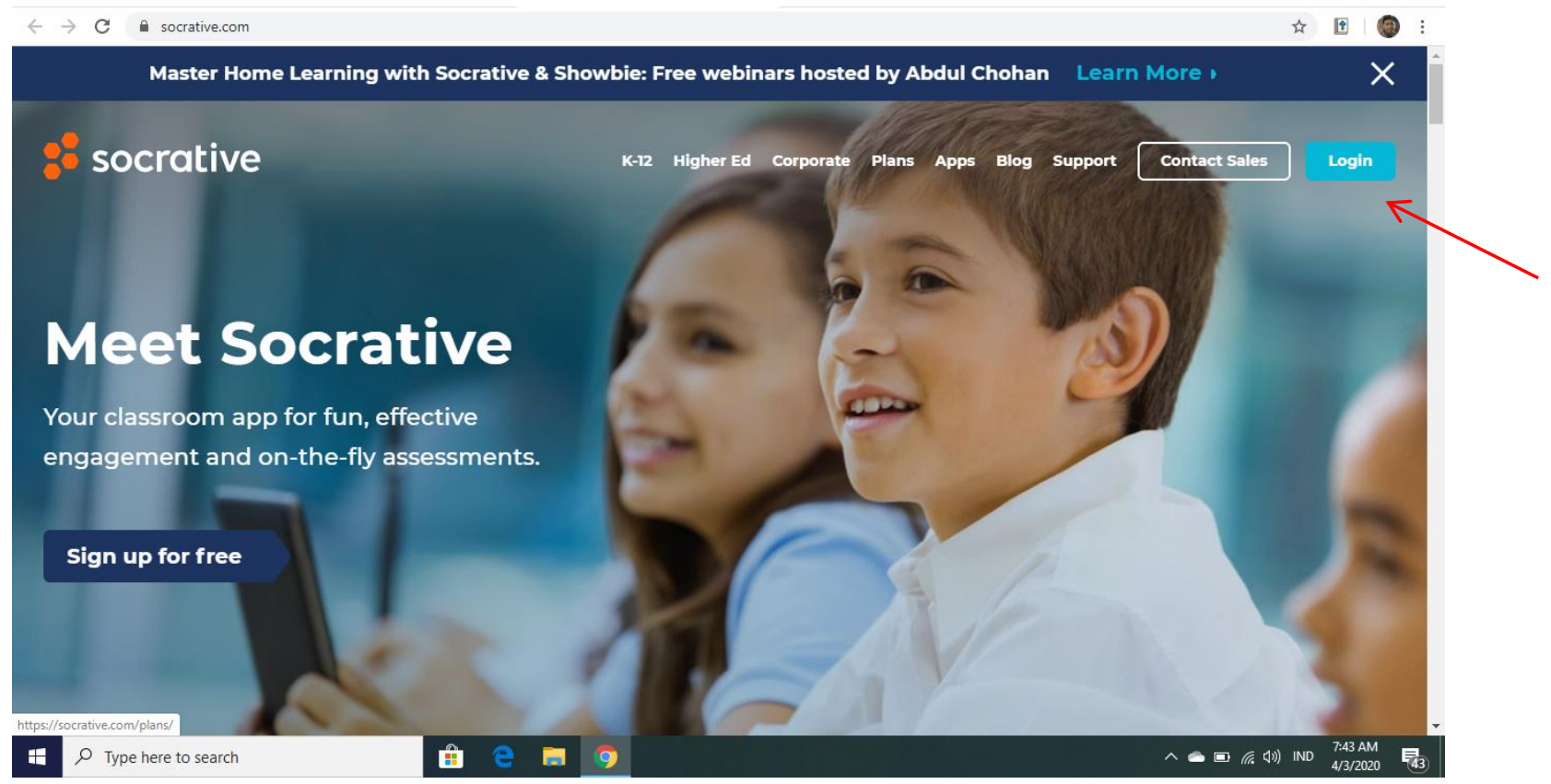




\section{Panduan Membuat Soal}

2. Setelah Login, pilihan akan muncul, untuk Student dan Teacher Klik, Teacher Login

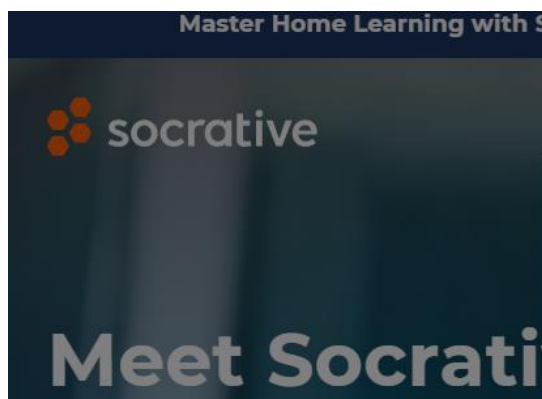

Your classroom app for fun, effect engagement and on-the-fly asses 


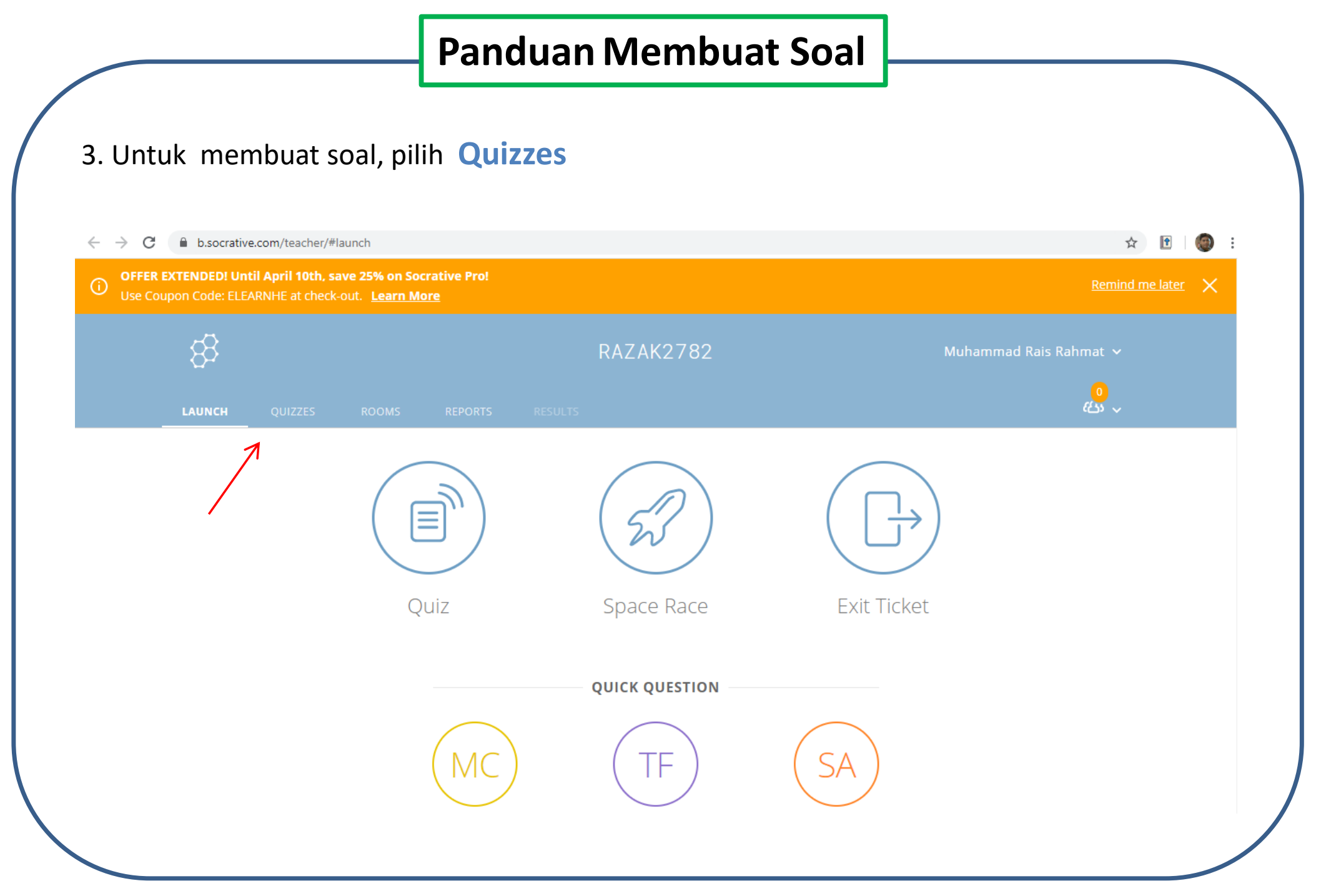




\section{Panduan Membuat Soal}

4.1. Klik, Add Quiz

muncul pihan create new dan import, misalnya pilih create new

2. muncul Nama Ruangan, contoh dibawah RAZAK2782 (di share ke mahasiswa)

3. ketik nama soal (misal KPP-coba1)

$\leftarrow \rightarrow$ C $@$ b.socrative.com/teacher/\#quizzes

is 19

(i) OFFER EXTENDED! Until April 10th, save $25 \%$ on Socrative Pro!

(i) Use Coupon Code: ELEARNHE at check-out. Learn More Remind me later $X$

8

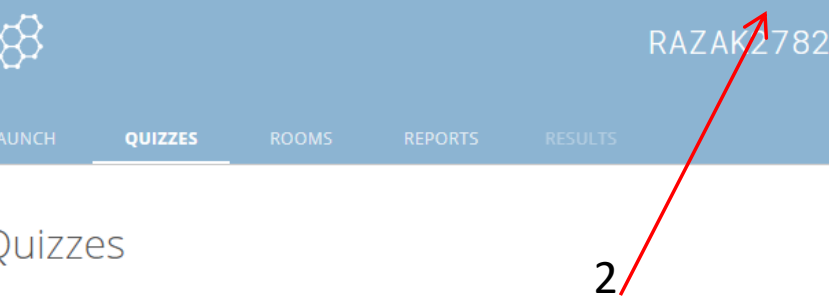

Muhammad Rais Rahmat

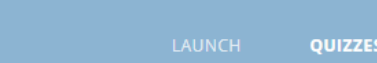

Quizzes

Q Search Quizzes

몽 FOLDERS

(III) DELETE $\leadsto$ MERGE $\underset{\rightarrow}{\rightarrow}$ MOVE

(థ) CREATE Folder

Quizzes

(iii) Trash

$\square$ ALL NAME $\uparrow$

DATE $\downarrow$

COPY DOWNLOAD SHARE

[ॄ Create folders and so much more! to Go PRO! Learn More 


\section{Panduan Membuat Soal}

5.1. Tulis nama soal yang akan dibuat (misal KPP-coba1) dan pilih jenis soal

2. Pilih Jenis soal yang akan dibuat Untuk pilihan ganda, Pernyataan benar/salah, Essay singkat

$\leftarrow \rightarrow$ C $\circ$ b.socrative.com/teacher/\#edit-quiz/45996751

s)

(i) OFFER EXTENDED! Until April 10th, save $25 \%$ on Socrative Pro

Remind melater $X$

8

Muhammad Rais Rahmat $~ ~$

cess $v$

\section{Create Quiz}

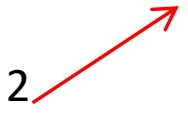

questions

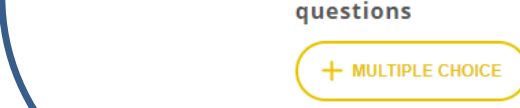




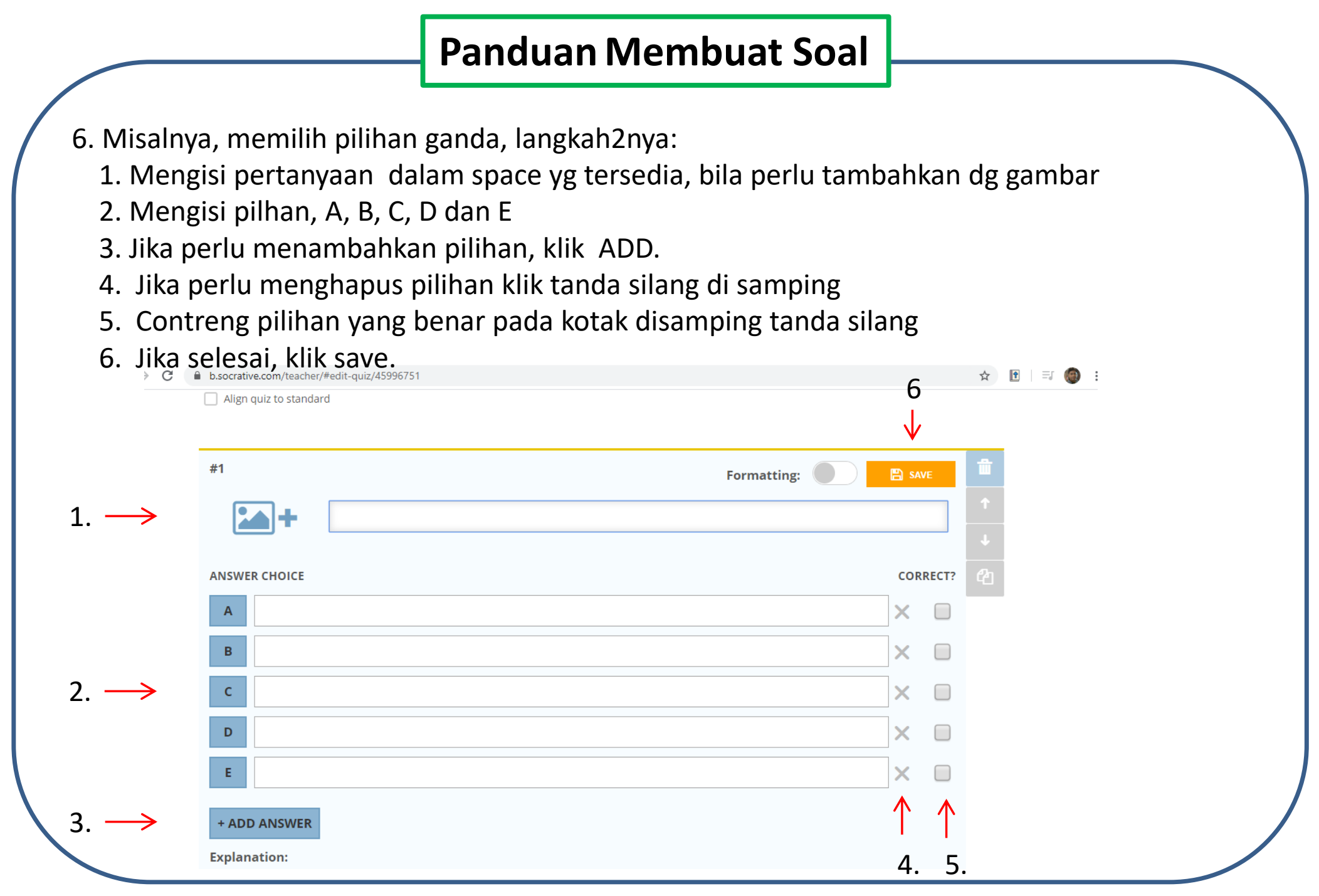




\section{Panduan Membuat Soal}

7. Mengisi soal,

1. Mengisi soal dan bisa dilengkapi dengan gambar

2. Setelah mengisi soal, klik Save . Contoh tampilan setelah mengisi soal

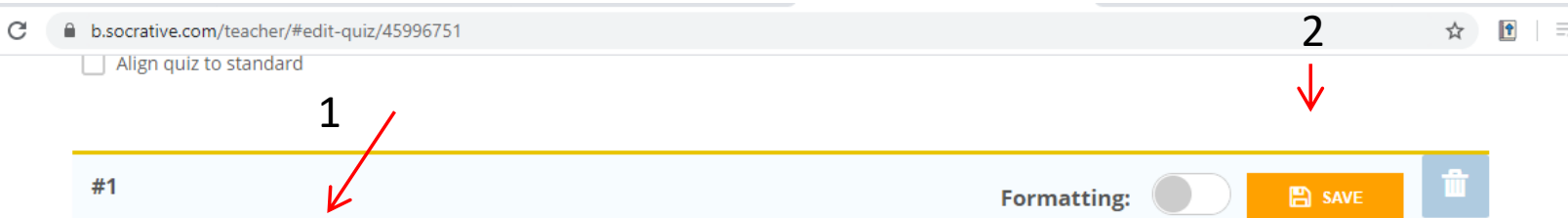

Ware

Formatting:

回 SAVE

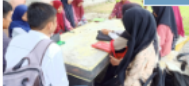

ANSWER CHOICE

CORRECT?

\begin{tabular}{|l|l|l|l|}
\hline A & Sumber inspirasi & $\times$ \\
\hline B & sumber pendanaan & \\
\hline C & sumber informasi atau berital & \\
\hline D & sumber bacaan & \\
\hline E & sumber air & \\
\hline
\end{tabular}

+ ADD ANSWER 


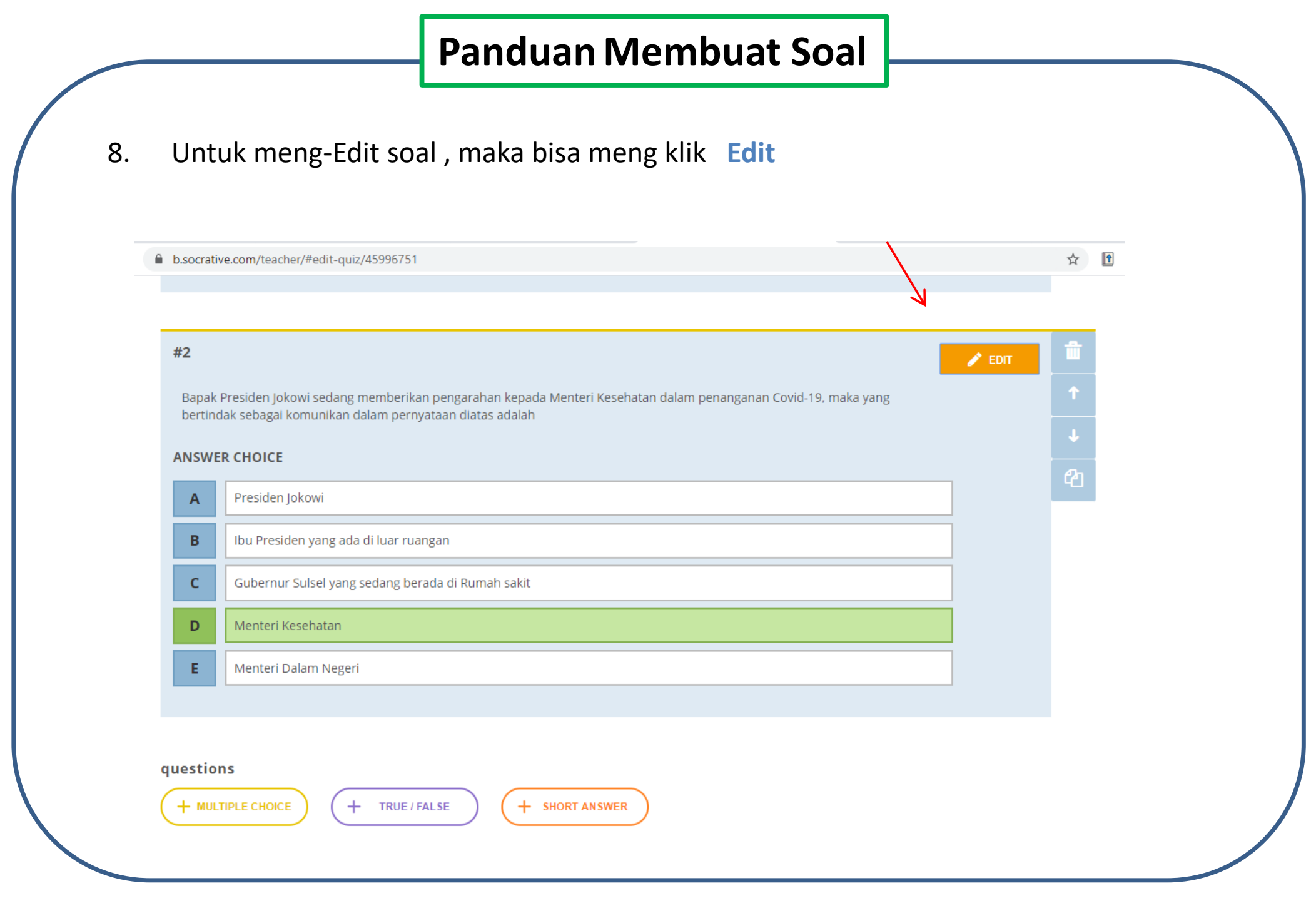




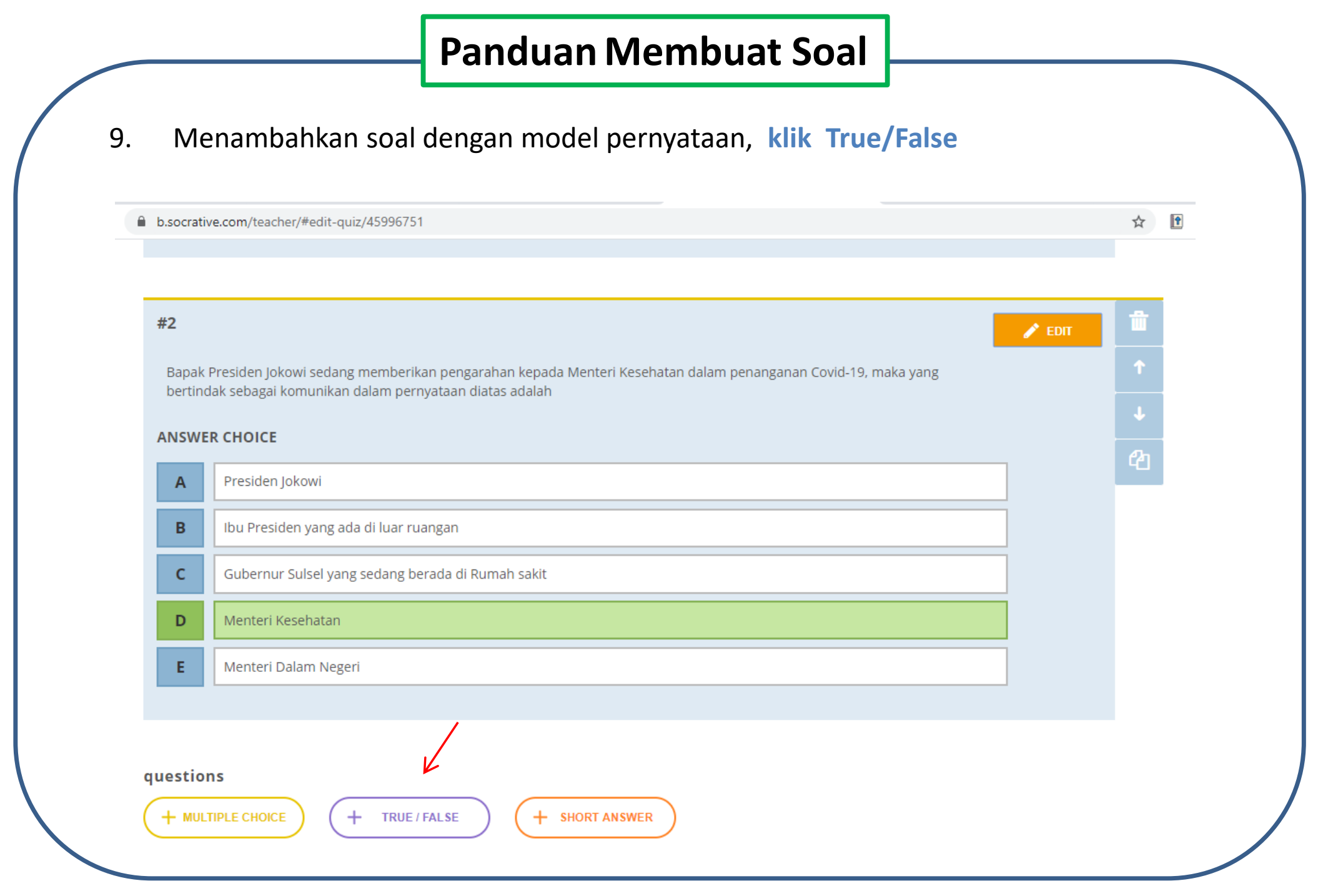




\section{Panduan Membuat Soal}

10. 1. Mengisi soal pernyataan

2. Mengklik jawaban yang benar, dengan klik kotak True (warna hijau)

3. Bila sudah yakin dengan soal dan jawaban dari pernyataan dibawah maka klik, Save

$\rightarrow$ C $\quad$ b.socrative.com/teacher/\#edit-quiz/45996751

ANSWER CHOICE

\begin{tabular}{|l|l|}
\hline A & Presiden Jokowi \\
\hline B & Ibu Presiden yang ada di luar ruangan \\
\hline C & Gubernur Sulsel yang sedang berada di Rumah sakit \\
\hline D & Menteri Kesehatan \\
\hline E & Menteri Dalam Negeri \\
\hline
\end{tabular}

3

$\downarrow$

\#3

Formatting:

回 SAVE

1. $\longrightarrow \quad$ Bupati termasuk Komunikator politik bersama dengan Ketua DPRD Sidenreng Rappang

Correct Answer:

2. $\longrightarrow \quad$ True $\quad$ False




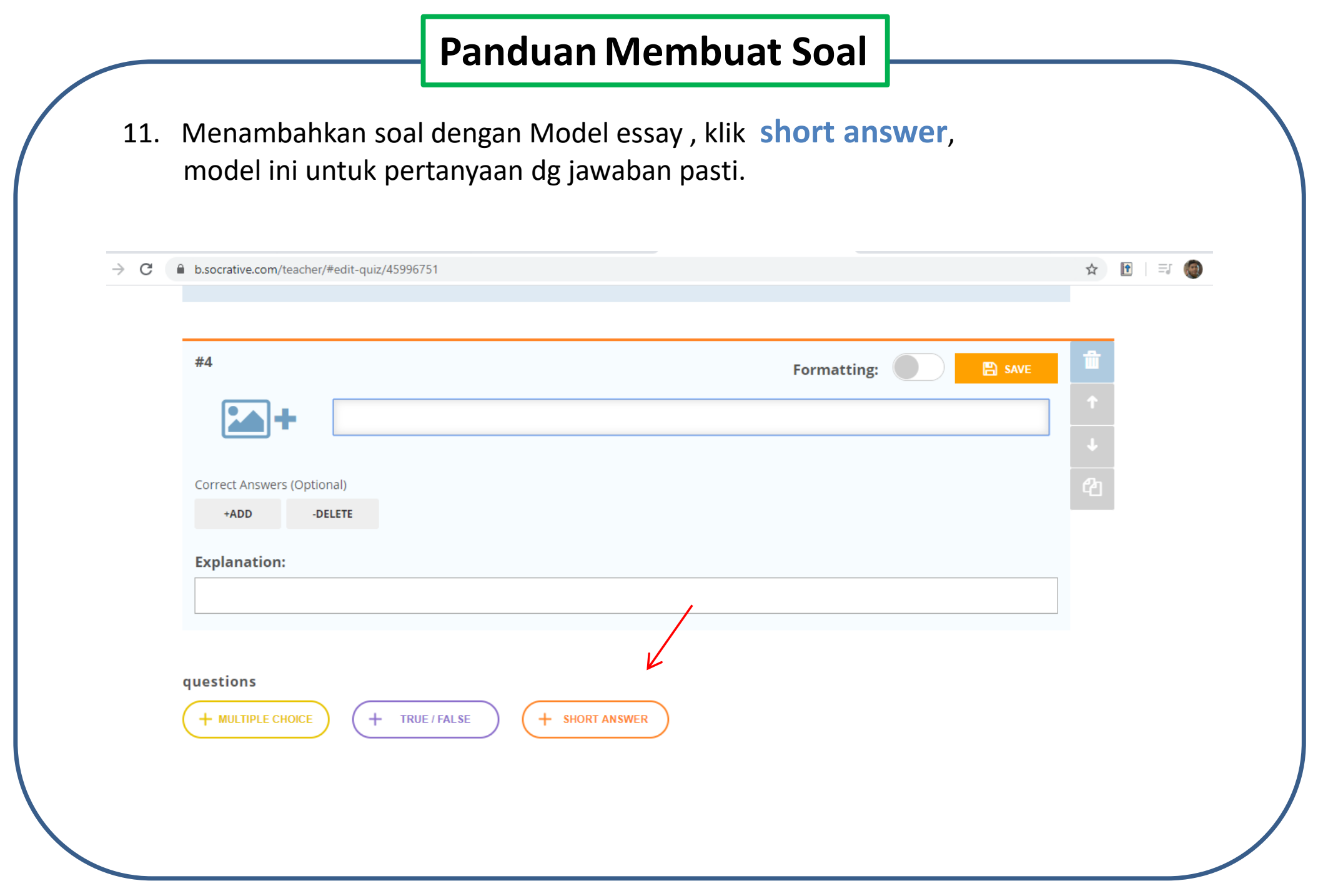




\section{Panduan Membuat Soal}

12.1. Mengisi soal, untuk jawaban yang singkat dan pasti

2. Mengisi jawaban

3. Menambah jawaban alternatife dengan meng klik +ADD

4. Mengisi jawaban alternatif

5. Menyimpan soal dengan, klik Yess

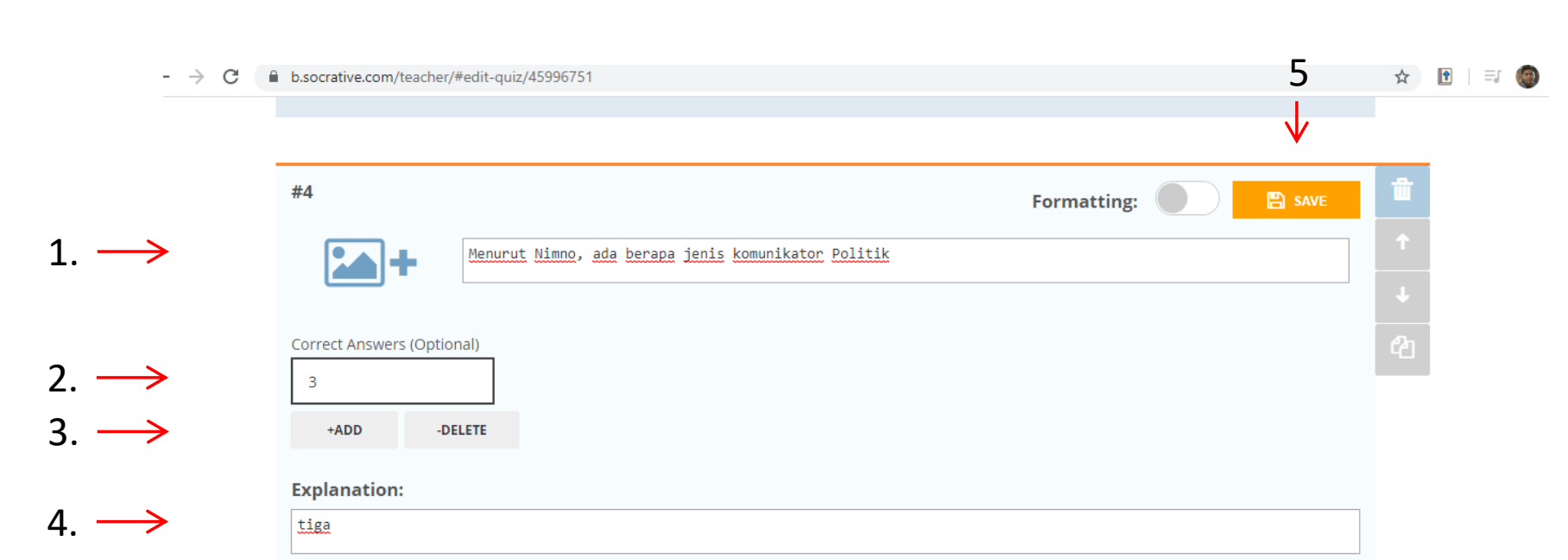

questions + multiplechoice + true/FAlse + short answer 


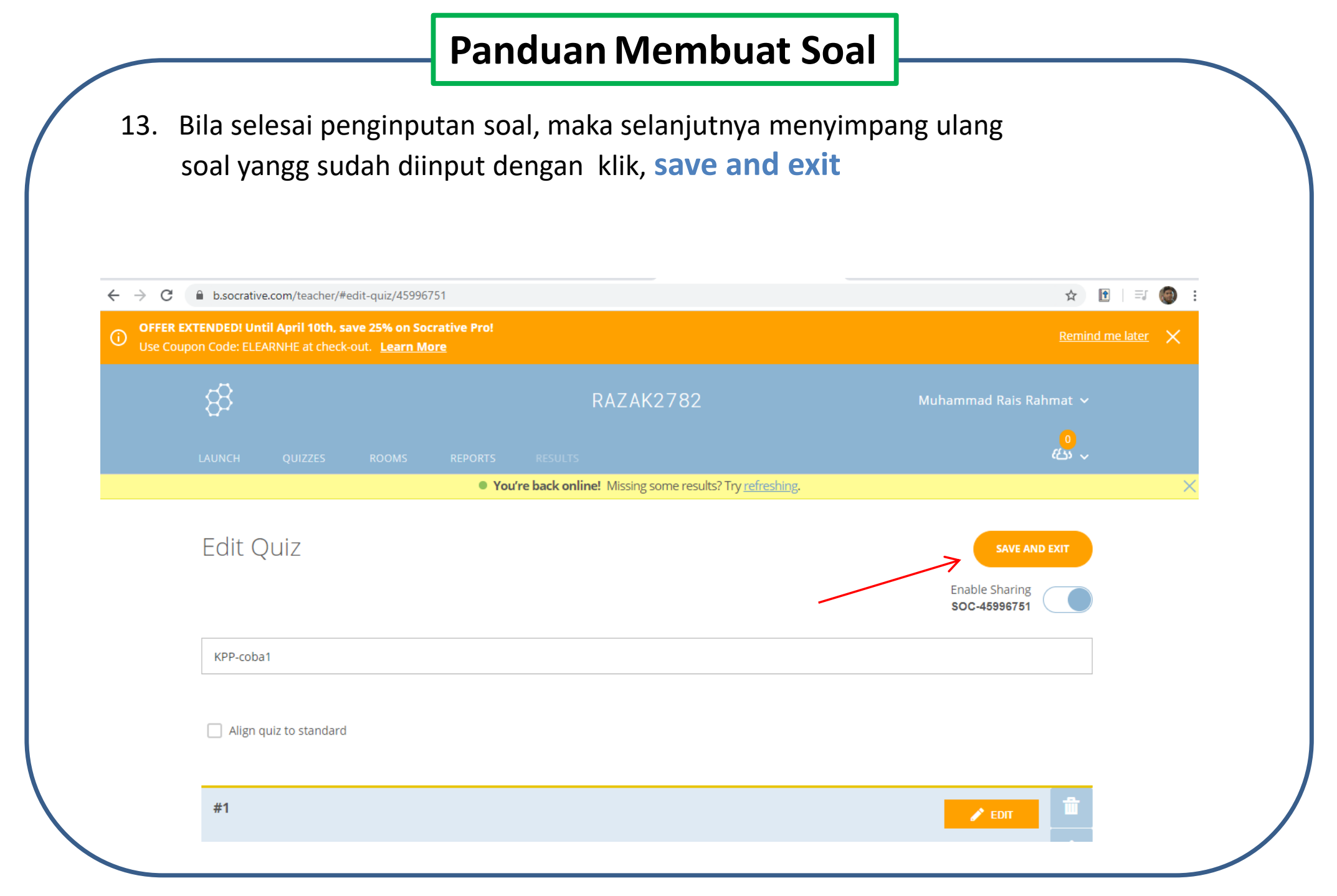




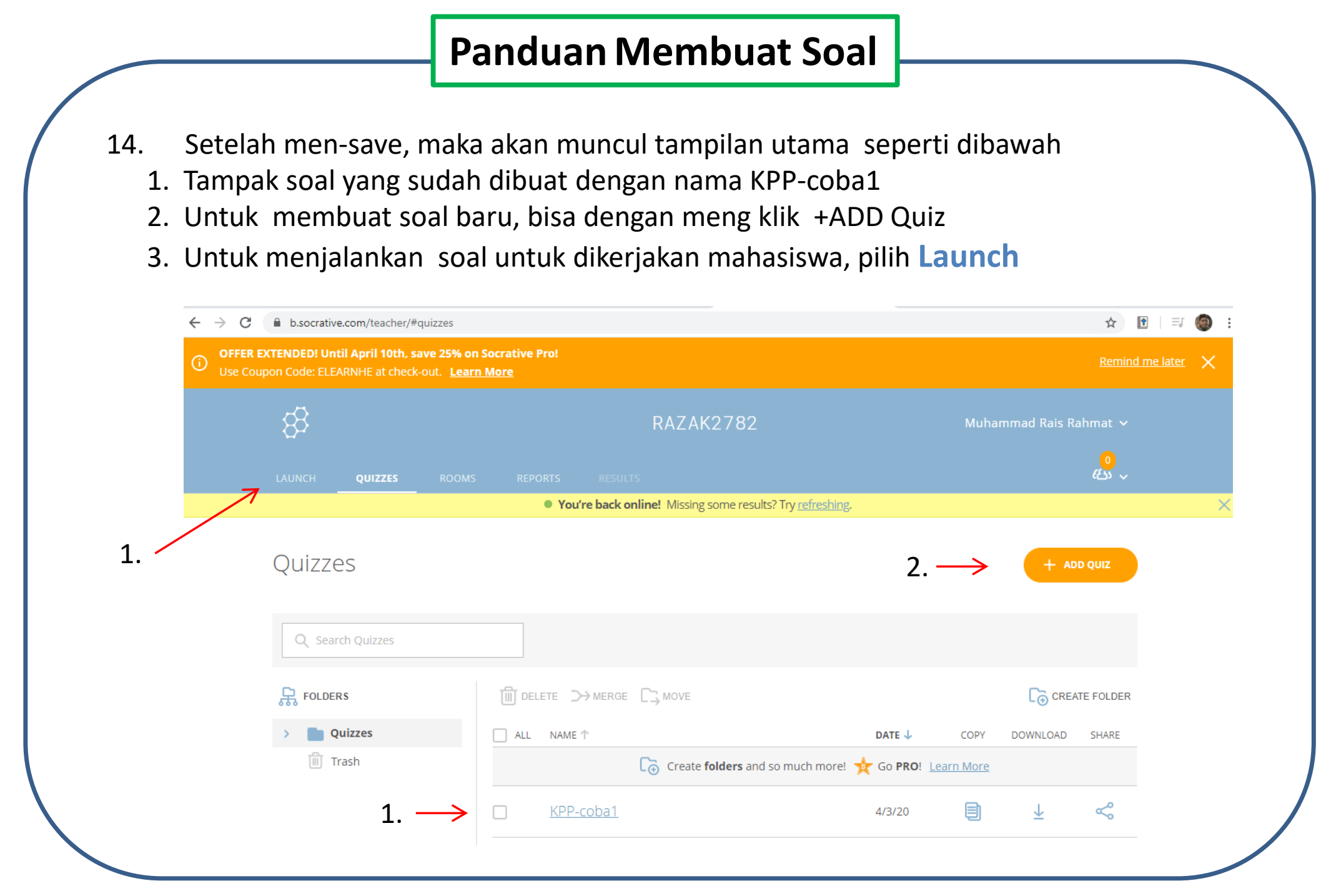




\section{Panduan Menjalankan Soal}

15. Setelah meng klik LAUNCH, maka muncul tampilan seperti dibawah

1. Jika melakukan ujian untuk peserta per orangan maka pilih, Quiz

2. Jika melakukan ujian untuk peserta per group, maka pilih space race

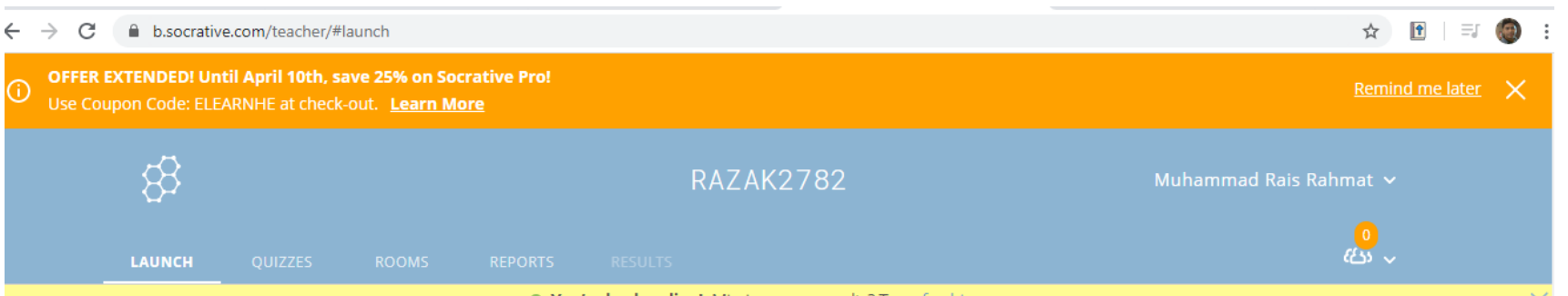

- You're back online! Missing some results? Try refreshing.

1. $\longrightarrow$

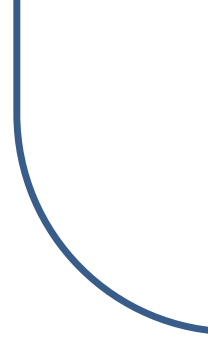

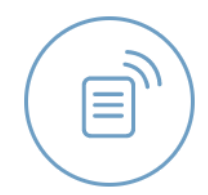

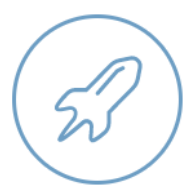

Space Race

2.

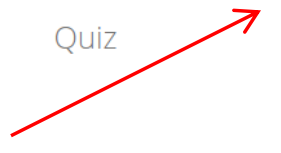

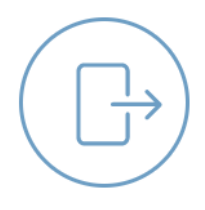

Exit Ticket
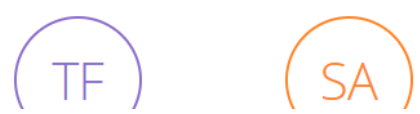


\section{Panduan Menjalankan Soal}

16. Setelah menk klik-QUIZ, Untuk melakukan ujian perorangan, muncul seperti tampilan dibawah

1. Pilih Nama soal yang mau dijalankan (soal yg sdh dibuat, contoh KPP-coba1

2. Kemudian Klik Next

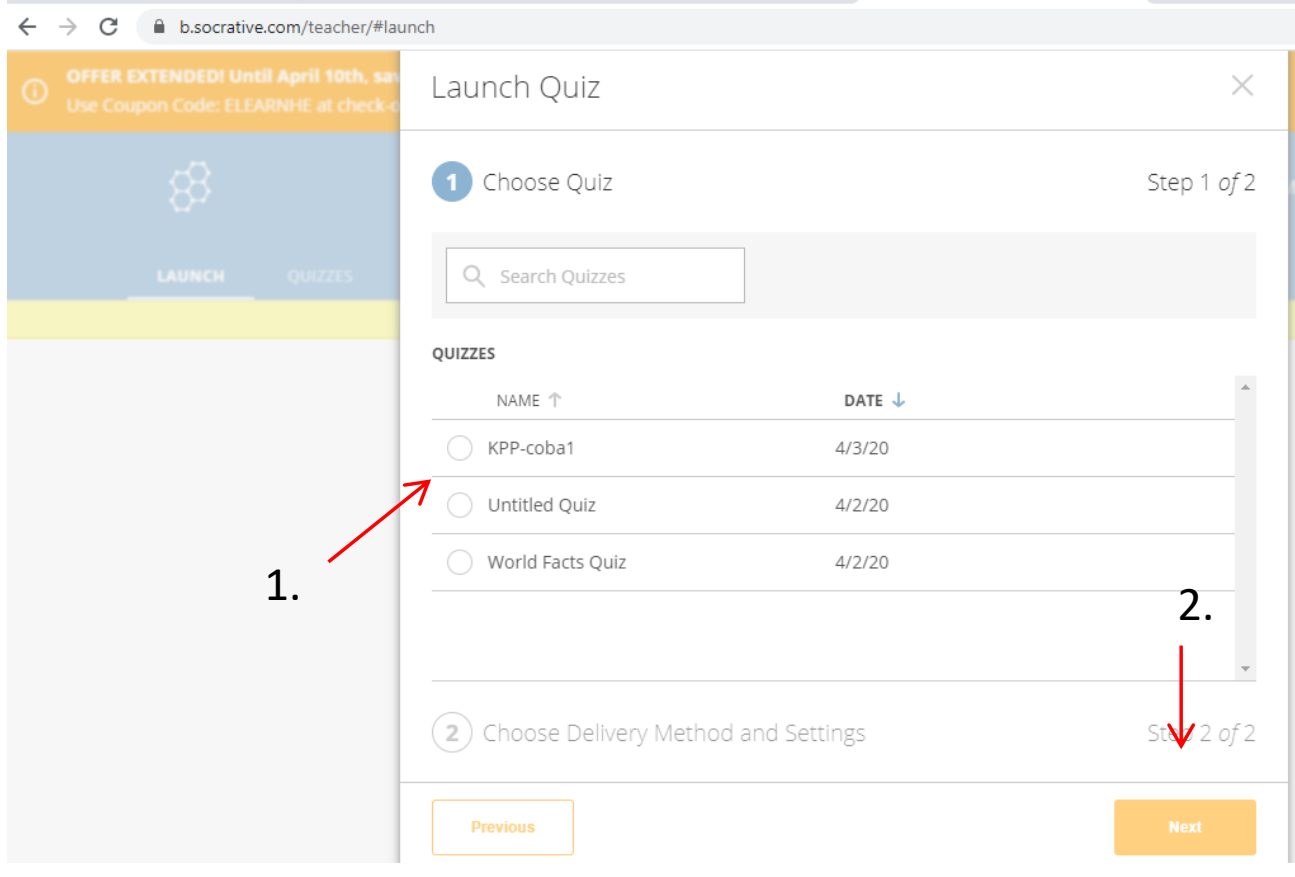




\section{Panduan Menjalankan Soal}

17. Model pengerjaan soal

1. Memilih instant feedback, pertanyaan akan dijawab satu persatu dan tdk bisa lompat, untuk menentukan kriterianya pastikan lingkaran kecil sebelahnya warna biru

2. require name berarti munculkan nama,

3. shuffel question (pertanyaan diacak),

4. shuffle answer (jawaban diacak),

5. show final score (hasil akhir dimunculkan). Setelah model soalnya disepakati,

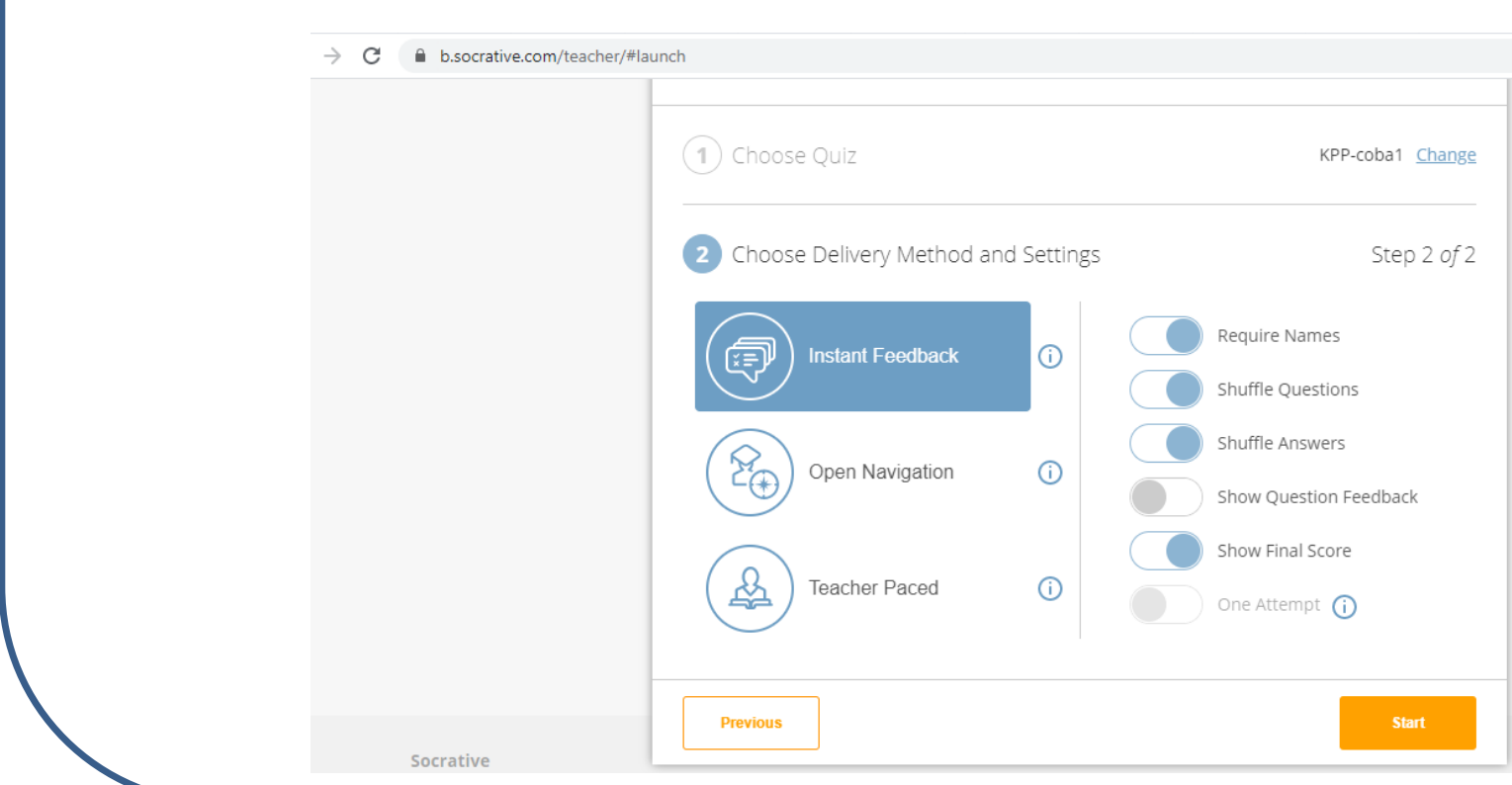




\section{Panduan Menjalankan Soal}

18. 1. Pilihan ini berarti, soal yang diterima oleh mahasiswa tidak ada yang sama baik, nomor urut maupun letak jawaban dan pada bagian akhir, akan muncul laporan berapa jawaban yang benar dan salah serta akan muncul score akhir.

2. Untuk menjalankan klik Start

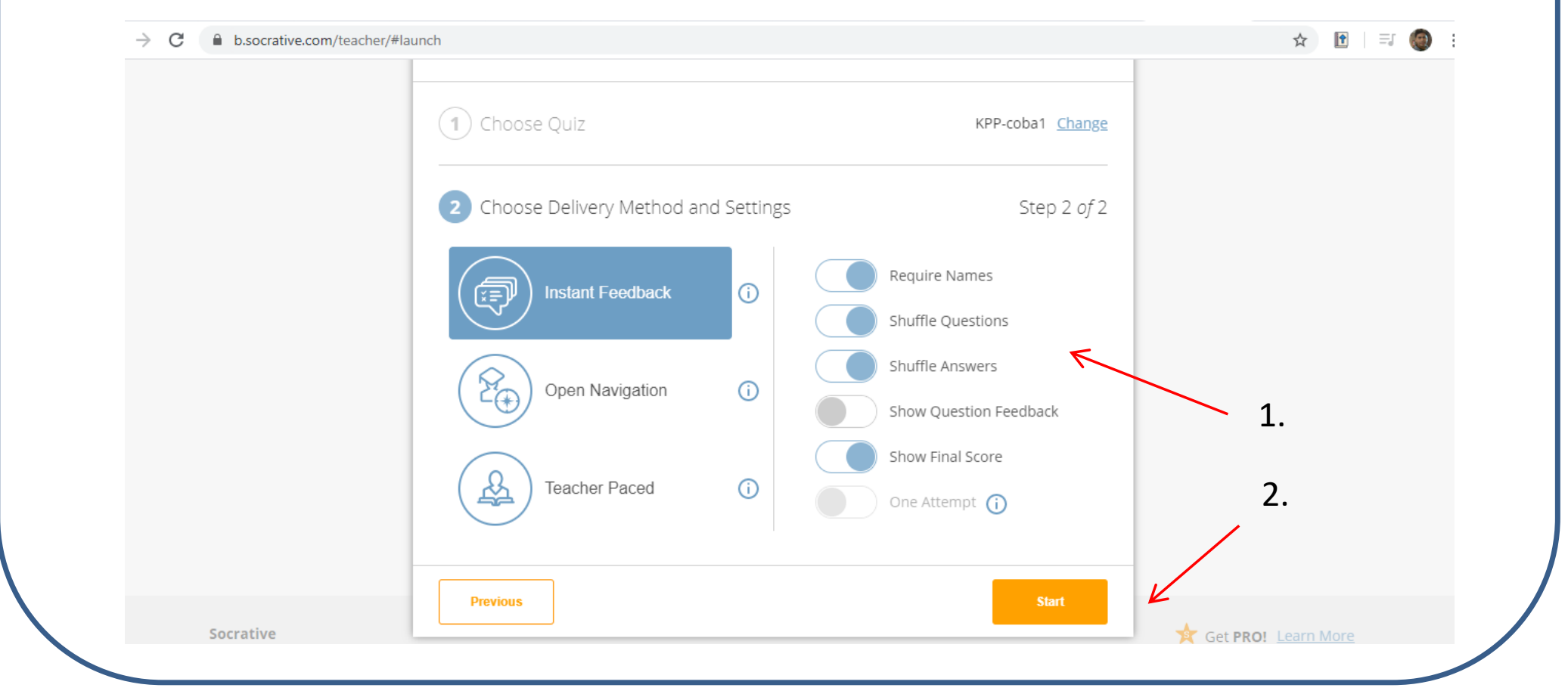




\section{Panduan Menjalankan Soal}

19. Setelah meng- Klik start, muncul tampilan seperti dibawah (belum ada mahasiswa mengerjakan). Selanjutnya mempersilahkan mahasiswa untuk mengerjakan soal , maka akan tampak dalam tabel progresnya

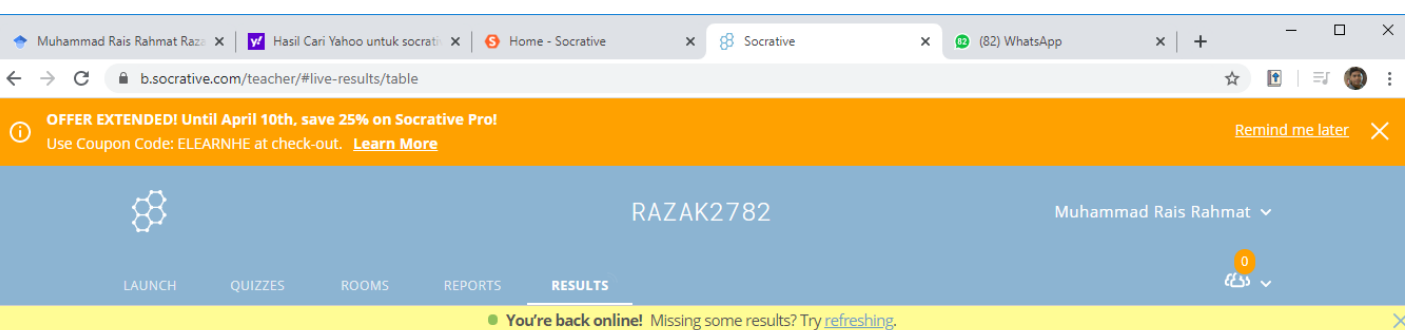

- Yoưre back online! Missing some results? Try refreshing.

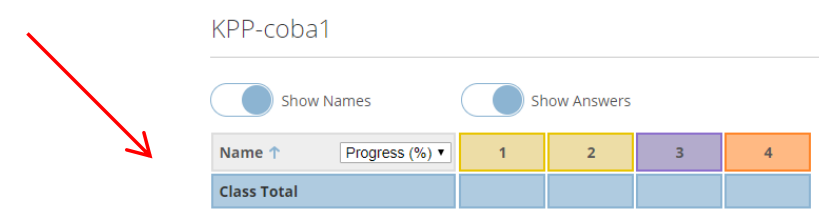

Click question numbers or class total percentages for detailed views. 


\section{Panduan Menjalankan Soal}

20. Setelah 3 mahasiswa (contoh) mengerjakan soal maka akan muncul tampilan

1. Urutan nomor soal

2. Nama peserta

3. Nilai prosentase

4. Progress pengerjaan soal per mahasiswa

5. Mengakhiri, ujian dengan meng-klik FINISH

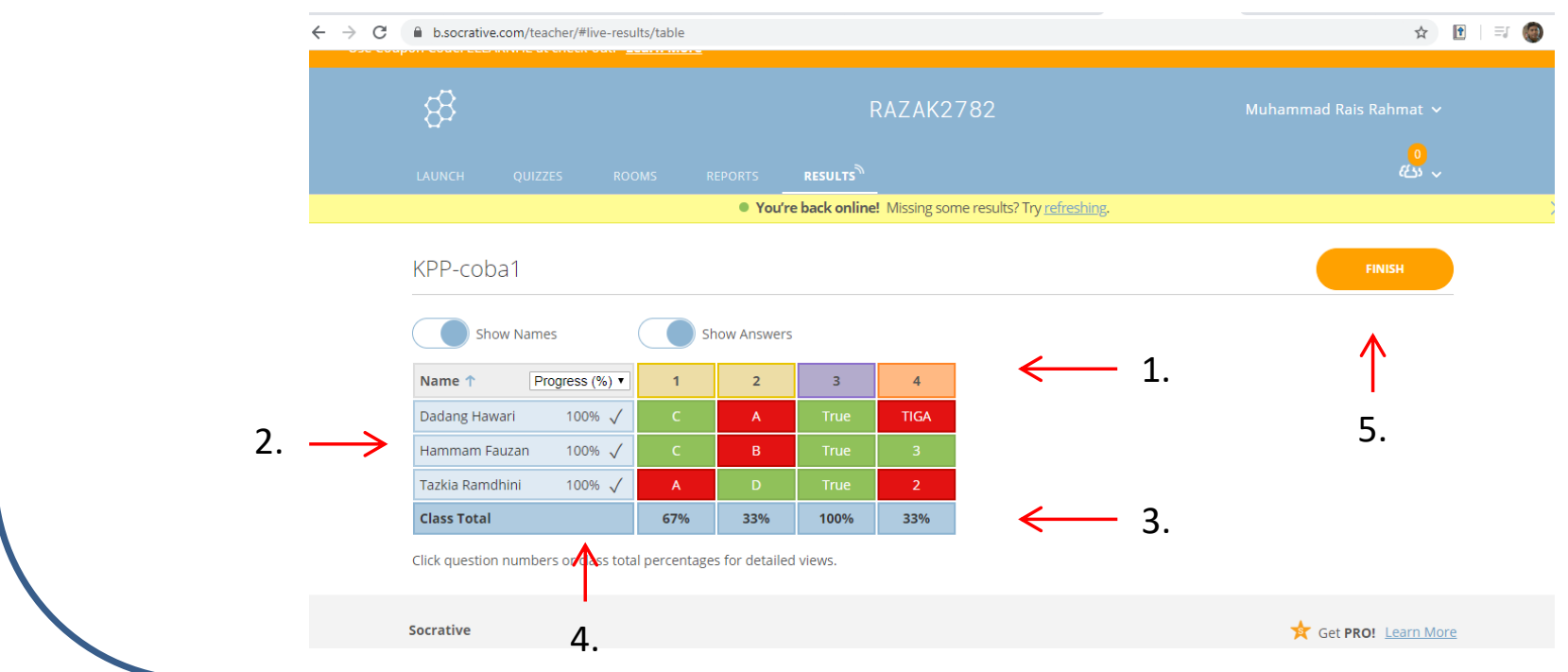




\section{SOCRATIVE untuk Mahasiswa (Mengikuti Ujian on Line)}




\section{Panduan Mengerjakan Soal}

1.1. Buka link atau cari di gogle atau mesin pencari lainnya dengan socrative, muncul www.socrative.com.

2. Klik, www.socrative.com maka muncul tampilan seperti dibawah ini, 3. Klik, Login

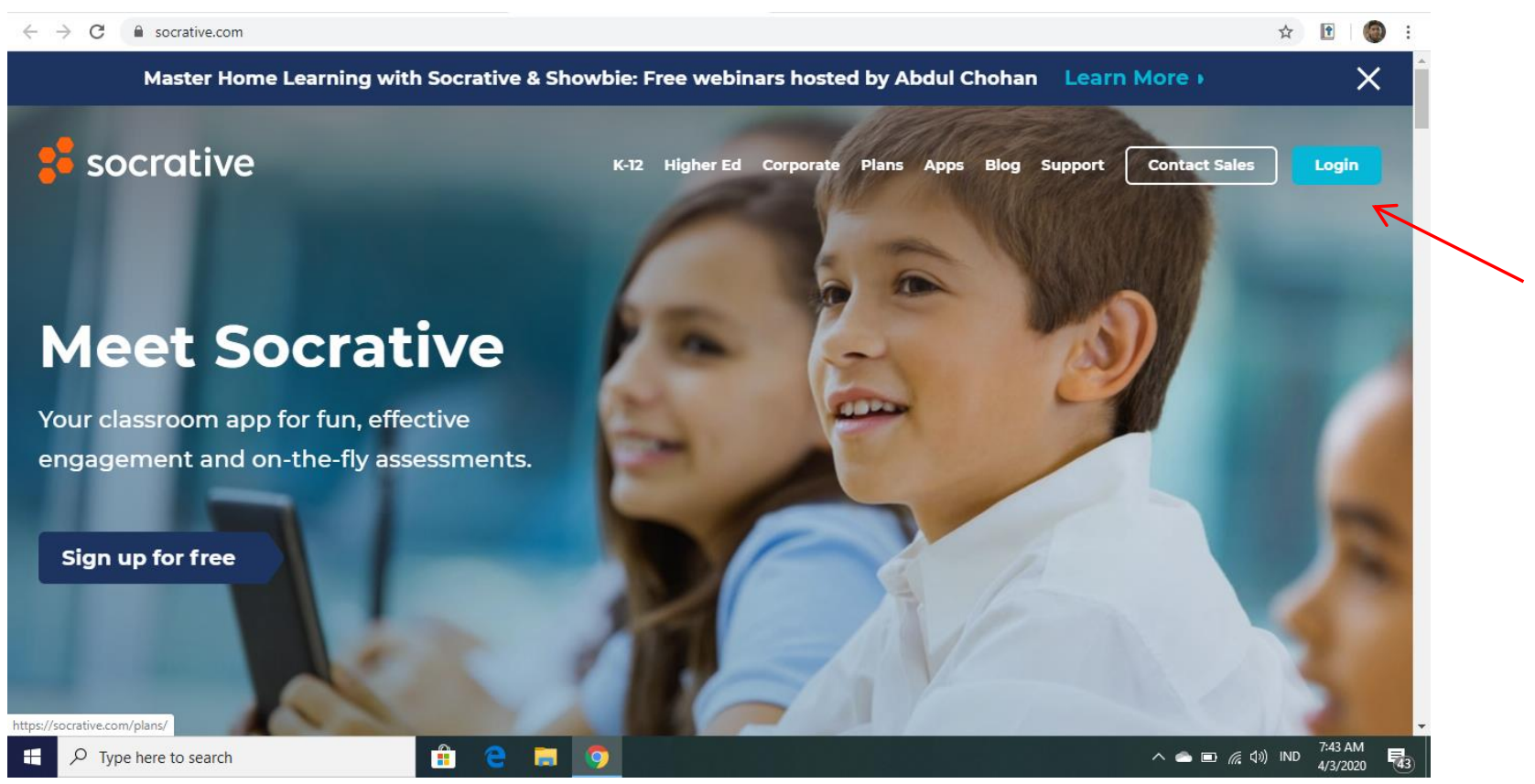




\section{Panduan Mengerjakan Soal}

2. Setelah Login, pilihan akan muncul, untuk Student dan Teacher Klik, Student Login

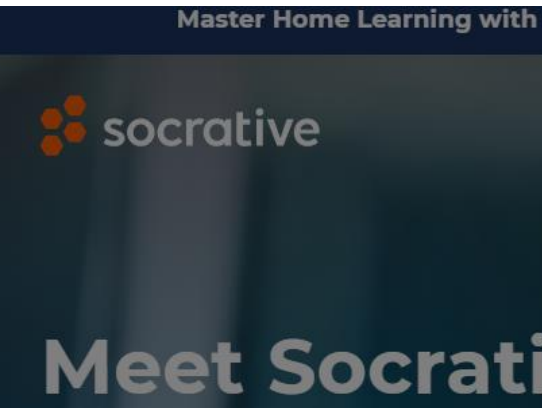

Your classroom app for fun, effect engagement and on-the-fly asses

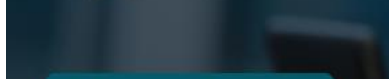

Sign up for free
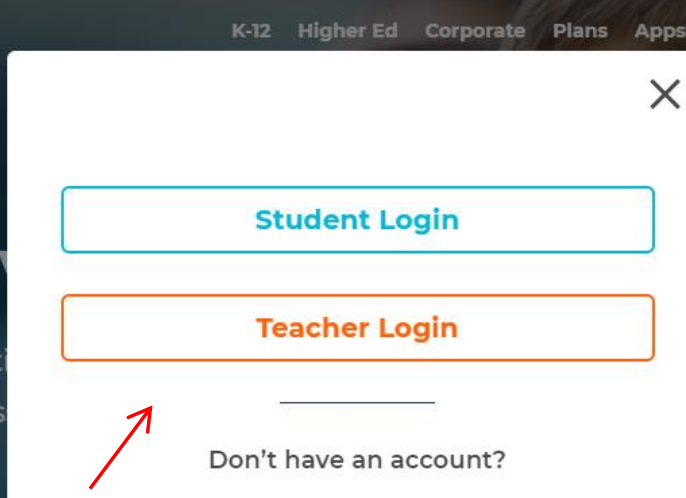

Don't have an account?

Sign up now! , 


\section{Panduan Mengerjakan Soal}

3. Setelah Meng-klik Student Login. Maka muncul tampilan seperti dibawah

1. Isi ROOM NAME, minta ROOM NAME dari DOSEN. contoh ini, isi dengan RAZAK2782

2. Kalau sudah benar, klik JOIN

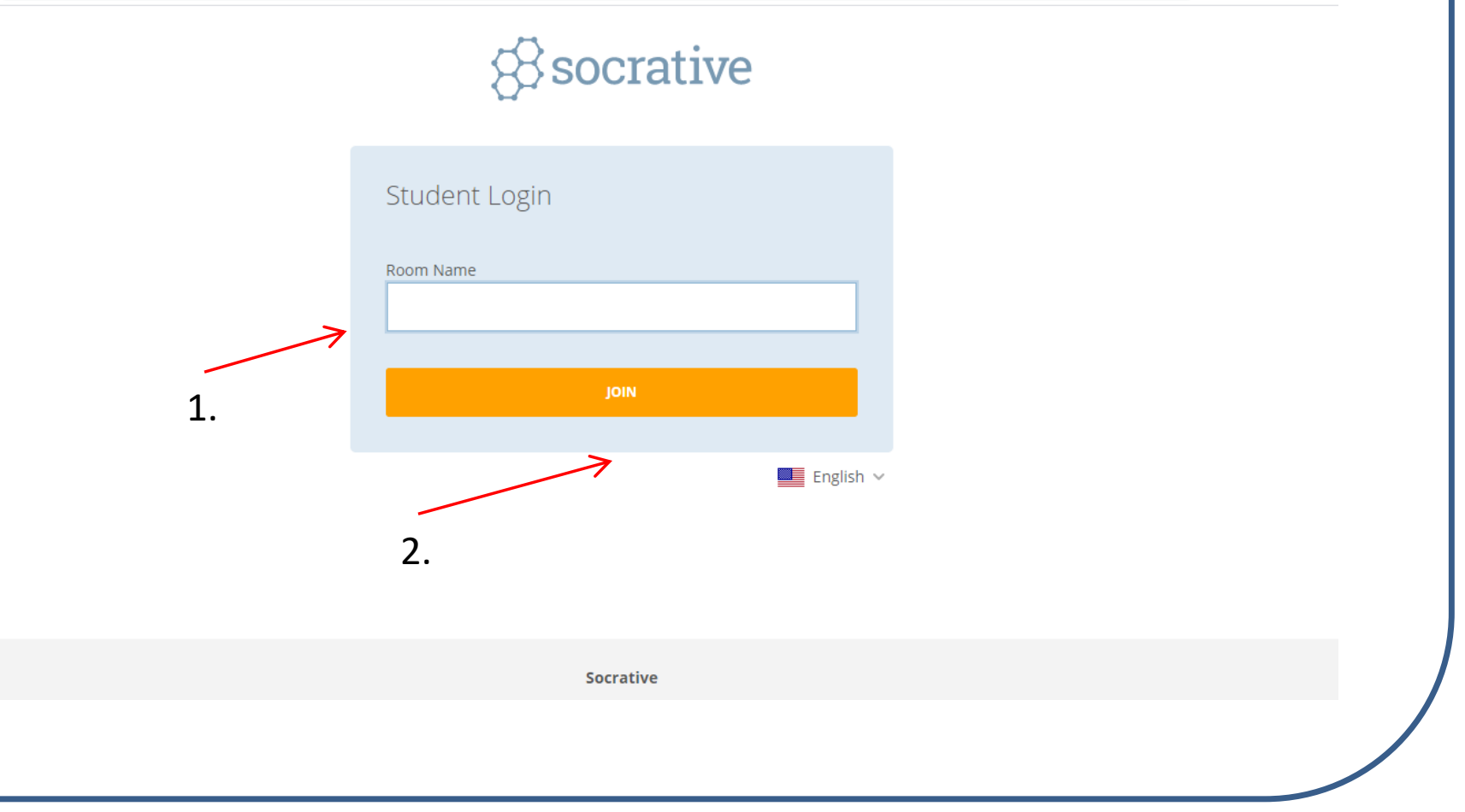




\section{Panduan Mengerjakan Soal}

4. 1. Setelah klik JOIN, muncul kotak isian, tulis Nama Lengkap Mahasiswa, contoh Hammam Fauzan,

2. Jalankan dengan meng-klik DONE

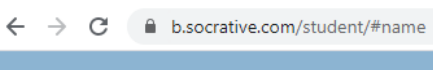

88

RAZAK2782

1
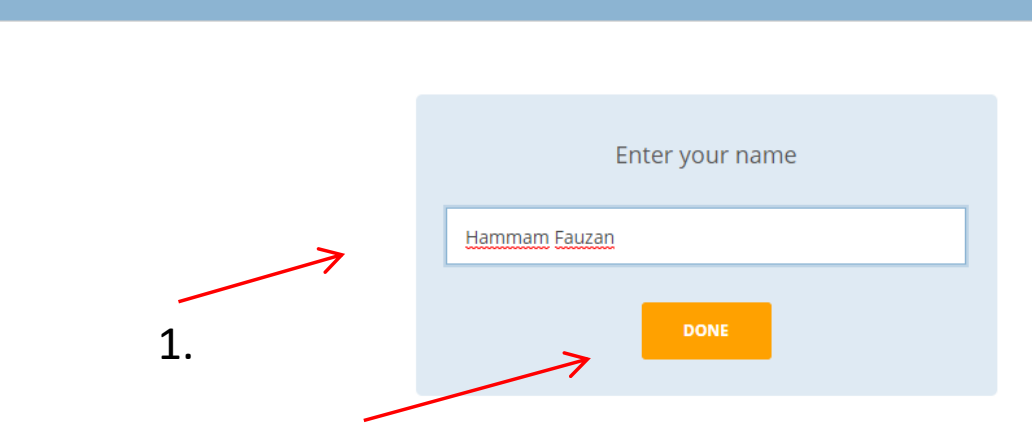

2. 


\section{Panduan Mengerjakan Soal}

5. 1, Selanjutnya Layar mahasiwa akan memunculkan pertanyaan. Soal yang muncul tidak sama nomor dan letak jawabannya setiap

2. Baca baik-baik soalnya kemudian pilih jawaban yang dianggap benar dengan meng-KLIK kemudian Kilk, SUBMIT ANSWER

Selesai men-submit answer, maka akan muncul nomor berikutnya. Sampai selesai
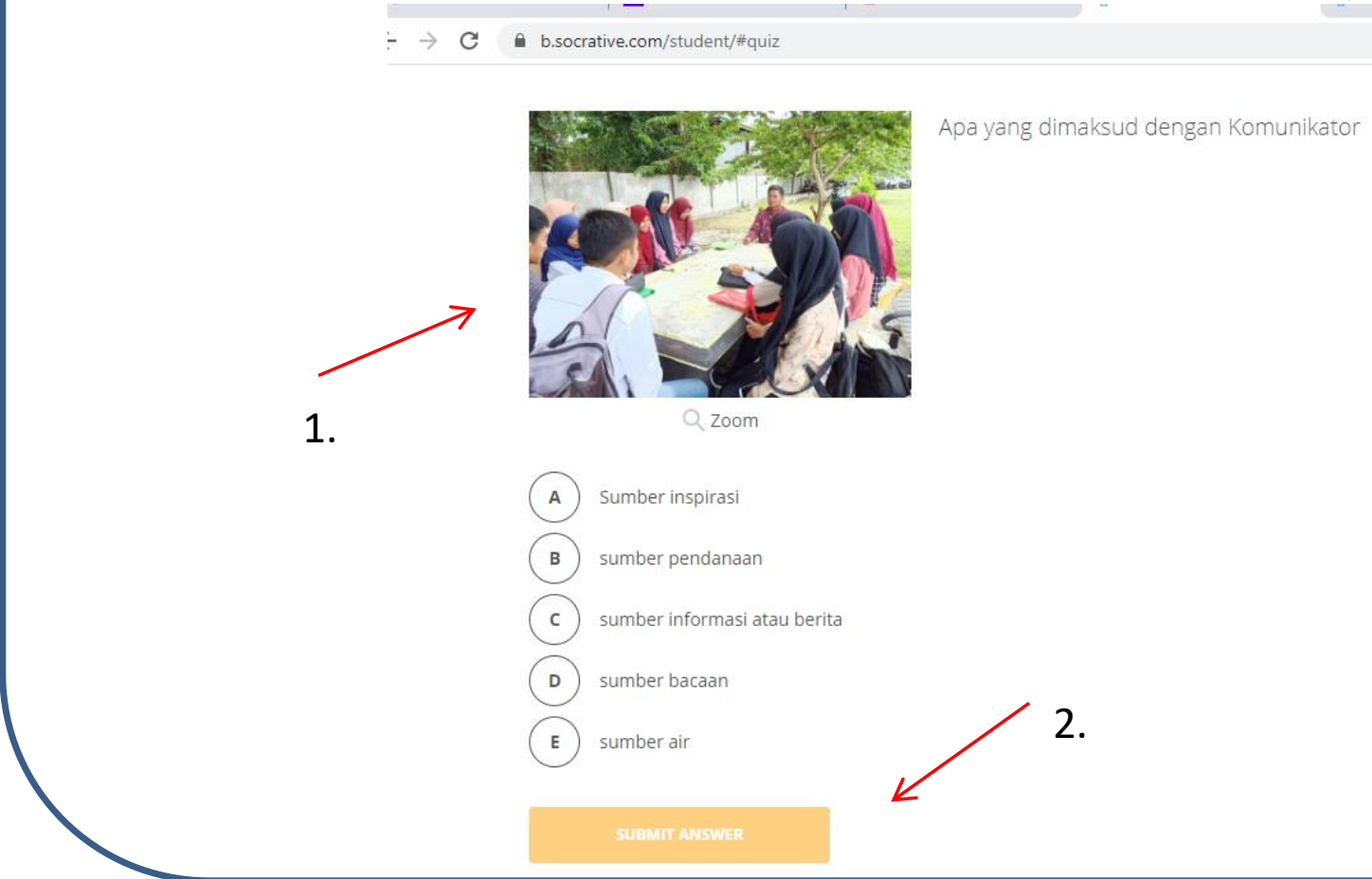

2. 


\section{Panduan Mengerjakan Soal}

6. 1. Setelah selesai mengerjakan semua soal, maka akan muncul final score

2. Selesai Ujian dengan mengklik, OK

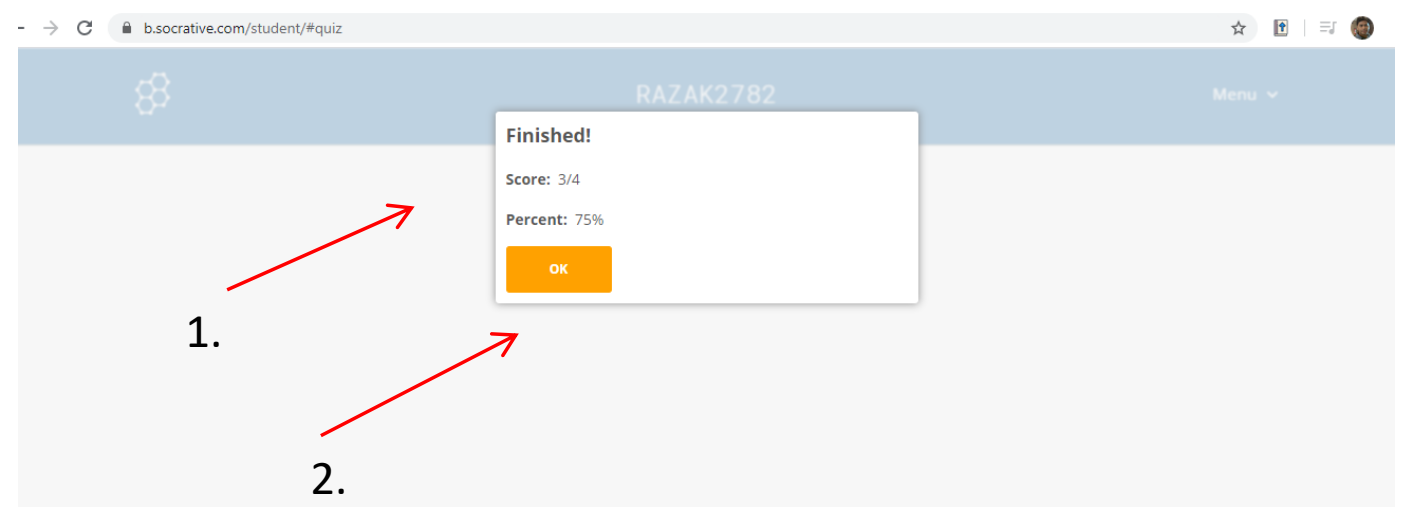




\section{Daftar Pustaka}

- Adul Chohan .Master home Learning with socrative \& Showbies: https://socrative.com/\#login Di akses 2 april 2020

- Ahza.Net (2019). Menjajal Socrative, Tool Assessment Gratis yang Fleksibel, Menarik dan Mudah Digunakan .http://www.ahzaa.net/2019/10/menjajal-socrative-toolassessment.html di akses 4 april 2020.

- $\quad$ Anang Yulianto. (2019). Menjalankan Soal https://www.youtube.com/watch?v=OarMlhProoQ.

- Novi Ivon (2017) Tutorial Socrative Berbahasa Indonesia. https://www.youtube.com/watch?v=3PGHeobHiNO di akses 2 April 2020

- Razak, M. R. R. (2020, March 9). Pemanfaatan Teknologi Informasi dalam Optimalisasi Pelayanan Publik dan Potensi Desa. https://doi.org/10.31219/osf.io/nfhu9

- Razak, M. R. R. (2020, March 9). Belajar Best Practice Ke Negeri Jiran. https://doi.org/10.31219/osf.io/vbf4u

- Razak, M. R. R. (2020, March 18). child social welfare institution participation in the implementation of good governance. https://doi.org/10.31219/osf.io/2t4ec

- Sri Wahyuni. (2019) video tutorial melaksanakan kuis di socrative. https://www.youtube.com/watch?v=6ie7aguEmug. Di akses 2 April 2020

- Suprapto; Razak, M. R. R. (2020, March 8). Job Stress of Nurses Associated With The Quality of Nursing Services at Hospital Emergency Services. https://doi.org/10.31219/osf.io/dzyc8

- Teacher's Technology Toolbox. (2015). https://www.youtube.com/watch?v=-XydEy-Mm 